\title{
EARTHQUAKE-INDUCED WATER-LEVEL FLUCTUATIONS AT YUCCA MOUNTAIN, NEVADA, APRIL, 1992
}

by Grady M. O'Brien

U.S. GEOLOGICAL SURVEY

Open-File Report 92-137

Prepared in cooperation with the

NEVADA FELD OFFICE,

U.S. DEPARTMENT OF ENERGY, under

Interagency Agreement DE-Al08-92NV10874 


\section{U.S. DEPARTMENT OF THE INTERIOR \\ MANUEL LUJAN, JR., Secretary}

U.S. GEOLOGICAL SURVEY

Dallas L. Peck, Director

For additional information write to:

Chief, Yucca Mountain Project Branch U.S. Geological Survey Box 25046, Mail Stop 421 Federal Center Denver, CO 80225-0046
Copies of this report can be purchased from:

U.S. Geological Survey Books and Open-File Reports Section Federal Center

Box 25425

Denver, CO 80225 


\section{CONTENTS}

Abstract .............................. 1

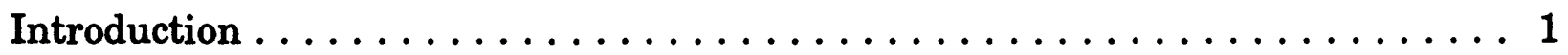

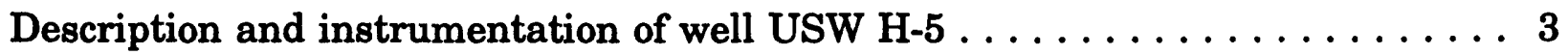

Earthquake-induced water-level fluctuations . . . . . . . . . . . . 3

Selected References . . . . . . . . . . . . . . . . . . . . . . . . . 10

\section{FIGURES}

Figure 1. Map showing geographic locations of earthquake epicenters . . . . . 2

2-5. Graphs showing well USW H-5 response to:

2. Earthquake near Palm Springs, California, occurring at 04:50 UTC, April 23, 1992 . . . . . . . . . . . . . . . . . . 5

3. Earthquake near Eureka, California, occurring at 18:06 UTC,

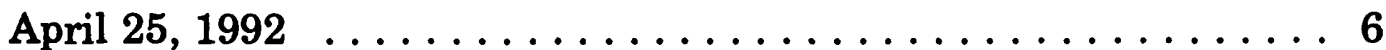

4. Earthquake near Eureka, California, occurring at 07:41 UTC, April 26, $1992 \ldots \ldots \ldots \ldots \ldots \ldots \ldots \ldots \ldots \ldots \ldots$

5. Earthquake near Eureka, California, occurring at 11:18 UTC, April 26, $1992 \ldots \ldots \ldots \ldots \ldots \ldots \ldots \ldots \ldots \ldots$

\section{CONVERSION FACTORS}

Multiply

millimeter (mm)

centimeter $(\mathrm{cm})$

meter $(\mathrm{m})$

kilometer $(\mathrm{km})$
By

0.03937

0.3937

3.281

0.6214
To obtain

inch (in.)

inch (in.)

foot ( $\mathrm{ft}$ )

mile (mi) 


\title{
Earthquake-Induced Water-level Fluctuations at \\ Yucca Mountain, Nevada, April, 1992 \\ by Grady M. O'Brien
}

\begin{abstract}
This report presents earthquake-induced water-level and fluid-pressure data for well USW H-5 during April 1992. Well USW H-5 is located in the Yucca Mountain area, Nevada. On April 22, 1992 a 6.2-magnitude earthquake occurred in southern California which caused a maximum fluid-pressure change of approximately 50 centimeters in well USW H-5. Within 18 hours on April 25-26, 1992, three major earthquakes occurred in northern California. The water-level responses to these earthquakes were detected in well USW H-5. The maximum water-level fluctuation from the northern California earthquakes was in excess of $52.5 \mathrm{~cm}$.
\end{abstract}

\section{INTRODUCTION}

The Yucca Mountain area in southern Nevada is being studied by the U.S. Department of Energy as a potential site for an underground high-level nuclear-waste repository (U.S. Department. of Energy, 1988). As part of that study, the U.S. Geological Survey monitors water levels in about 25 wells to define the potentiometric surface, determine long-term and seasonal water-level changes, and estimate hydraulic properties using short-term water-level fluctuations. Frequency of monitoring ranges from quarterly to continuous with most measurements being done either monthly or hourly. Monthly measurements are sufficient to detect long-term and seasonal changes, whereas hourly measurements are required to detect changes induced by barometric-pressure fluctuations and earth tides. Only continuous measurements are capable of detecting seismically induced water-level fluctuations.

During late April 1992, the water-level response to earthquakes in California was detected at well USW H-5 on the crest of Yucca Mountain just west of the Nevada Test Site (fig. 1) (lat $36^{\circ} 51^{\prime 22} 2^{\prime N}$., long $116^{\circ} 27^{\prime} 55^{\prime \prime W}$.). Water-level and fluidpressure data collected from well USW H-5 during the period of the earthquakes are presented in this report.

Hydroseisms, or water-level fluctuations in response to earthquakes, are relatively common phenomena observed in wells penetrating confined aquifers (Todd, 1980, p. 250-252). For example, the Anchorage, Alaska earthquake of 1964, the largest North American earthquake thus far in the 20th century, caused water-level fluctuations throughout the world; the largest peak-to-trough range was about $7.0 \mathrm{~m}$ (meters) in a well in South Dakota (Vorhis, 1967, p. 32). Hydroseisms are more commonly in the centimeters-to-meter range and typically are observed for minutes to tens of minutes. Hydroseisms roughly resemble damped oscillation curves but are 


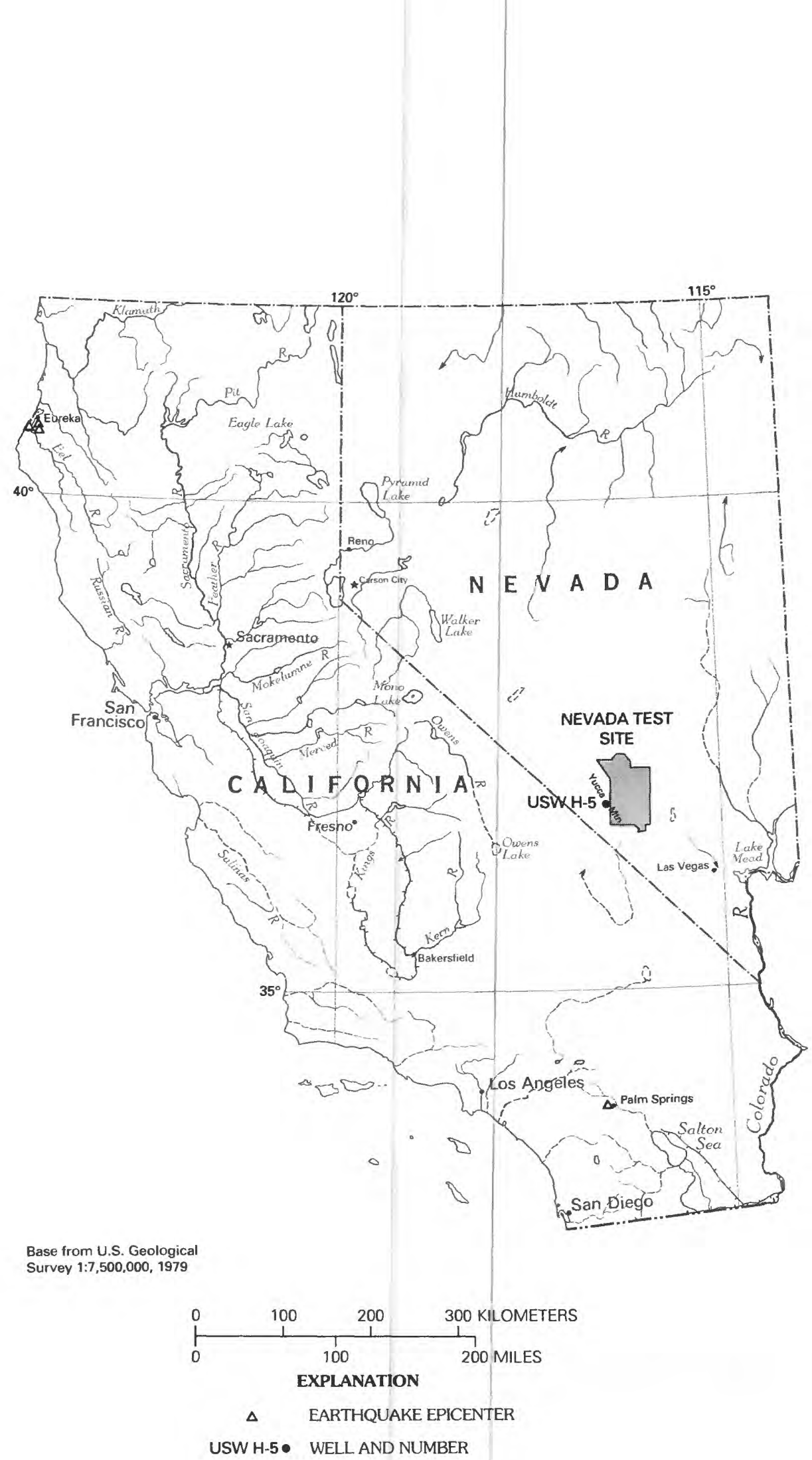

Figure 1.--Geographic locations of earthquake epicenters. 
somewhat more complicated because several different types of seismic waves participate in the phenomena. Relatively small dilatational $(\mathrm{P})$ and shear $(\mathrm{S})$ body waves are followed by long-period surface waves. Distant earthquakes generating longperiod surface waves can produce water-level fluctuations somewhat larger than aquifer-pressure changes. However, short-period body waves probably predominate during local seismic events and produce aquifer-pressure changes much larger than water-level fluctuations. Rayleigh surface waves from earthquakes, with depths less than $15 \mathrm{~km}$ (kilometers), produce the largest water-level fluctuations in wells several degrees from the earthquake epicenter (Eaton and Takasaki, 1959, p. 227-229).

\section{DESCRIPTION AND INSTRUMENTATION OF WELL USW H-5}

Well USW H-5 was drilled to a depth of $1,219 \mathrm{~m}$ and cased to a depth of 788 $\mathrm{m}$. The well penetrates various volcanic units of Tertiary age. Approximate depth to water is $703 \mathrm{~m}$, and the water-level altitude in this well is approximately $775 \mathrm{~m}$. The well contains two intervals separated by a packer located at a depth of $1,091 \mathrm{~m}$. The upper interval is a free water surface and is used to monitor the water level in the Bullfrog and Tram Members of the Crater Flat Tuff and a lower lava flow. The lower interval of the well is used to monitor the fluid pressure in an unnamed lava flow beneath the Crater Flat Tuff (Robison and others, 1988). The lower interval access tube is equipped with an air-inflatable small-diameter packer so that fluid pressure (rather than free water surface) is measured. The packer configuration in the lower interval eliminates well storage as well as viscosity and inertia effects that retard the movement of water as it flows to and from the well. Fluid-pressure measurements in the lower interval detect rapidly changing aquifer pressure induced by short-period earthquake waves. Due to the time required for water to move into and out of the well a free water surface can not respond efficiently to short-period earthquake waves (Leggette and Taylor, 1935).

To detect seismically induced water-level fluctuations, continuous monitoring of wells is required. Well USW H-5 has been equipped to monitor seismic events since March 17, 1992. The data-collection system in the upper and lower intervals of the well consists of gauge pressure transducers with 5 pounds per square inch pressure ranges. The pressure transducers are continuously powered, and the output is recorded on an analog chart recorder. The chart recorder prints the transducer output and grid simultaneously so that no signal distortion or chart drift occurs. Chart speed is set to 1 millimeter per minute, and the full-scale range for each interval is $\mathbf{5 0}$ millivolts. The chart scale was chosen so that local small-magnitude earthquakes, underground nuclear explosions (UNE), and distant earthquakes could be detected.

\section{EARTHQUAKE-INDUCED WATER-LEVEL FLUCTUATIONS}

Four earthquakes in California during late April, 1992 produced measurable water-level and fluid-pressure fluctuations in well USW H-5. Sections of the analog chart that recorded the effects of the four earthquakes in well USW H-5 are shown 
in figures 2-5. Earthquake information was obtained from the U.S. Geological Survey National Earthquake Information Center Quick Epicenter Determination system.

The water-level and fluid-pressure response to a southern California earthquake near Palm Springs (fig. 1), at 4:50:23 Universal Time (UTC), April 23, 1992 (8:50:23 pm PST, April 22) is shown in figure 2. The 6.2-magnitude earthquake occurred at lat $34^{\circ} 2^{\prime} 2^{\prime \prime} \mathrm{N}$., long $116^{\circ} 26^{\prime} 13^{\prime \prime} \mathrm{W}$. The earthquake was reportedly felt in the Las Vegas area. The distance from epicenter to well USW H-5 was approximately $311 \mathrm{~km}$, and the first water-level response was detected at 04:51 UTC. Standard continental crust $P$-wave velocity of $8 \mathrm{~km}$ per second and Rayleigh wave (18-20 second period) velocity of $3 \mathrm{~km}$ per second provide good correlation in well USW H-5 between expected seismic wave arrival time and water-level response. Water-level fluctuations caused by the arrival of $P$-waves and Rayleigh waves are difficult to distinguish in figure 2, probably due to the relatively short distance from earthquake epicenter to well USW H-5 and the compressed time scale. Well USW H-5 waterlevel response to the $\mathrm{P}$-wave is smaller in magnitude and precedes the Rayleigh wave which produces the maximum water-level fluctuations (fig. 3-5). The peak water-level rise and fall in the upper interval were approximately $14.6 \mathrm{~cm}$ (centimeters) and -11.5 $\mathrm{cm}$. The fluctuations damped to $1 \mathrm{~cm}$ in about 19 minutes. The peak fluid-pressure rise in the lower interval was off scale and, thus, exceeded $23.4 \mathrm{~cm}$; the peak fluidpressure fall was $-26.5 \mathrm{~cm}$ of water. The fluctuations damped to $1 \mathrm{~cm}$ in about 26 minutes.

Three major earthquakes occurred within 18 hours on April 25-26, 1992 in northern California (fig. 1). Significant damage and injuries were reported in the Eureka, California area. The water-level and fluid-pressure response to the northern California earthquake at 18:06:04 UTC, April 25, 1992 is shown in figure 3. The 7.0magnitude earthquake occurred at lat $40^{\circ} 20^{\prime 2} 24^{\prime \prime} \mathrm{N}$., long $124^{\circ} 2^{\prime 2} 28^{\prime \prime} \mathrm{W}$. The distance from epicenter to well USW H-5 was approximately $767 \mathrm{~km}$, and the first water-level response was detected at 18:08 UTC. The initial, small-magnitude, water-level fluctuations were caused by $\mathrm{P}$-wave arrivals; the maximum water-level fluctuations were caused by Rayleigh waves (fig. 3). The peak water-level rise and fall in the upper interval of the well were off scale and, thus, exceeded $33.1 \mathrm{~cm}$ and $-19.4 \mathrm{~cm}$. The fluctuations damped to $1 \mathrm{~cm}$ in about 76 minutes. The peak fluid-pressure rise in the lower interval was off scale and, thus, exceeded $23.0 \mathrm{~cm}$; the peak fluidpressure fall was $-26.1 \mathrm{~cm}$ of water. The fluctuations damped to $1 \mathrm{~cm}$ in about 97 minutes.

The water-level and fluid-pressure response to the northern California earthquake at 07:41:40 UTC, April 26, 1992, is shown in figure 4. The 6.5-magnitude earthquake occurred at lat $40^{\circ} 25^{\prime} 19^{\prime \prime} \mathrm{N}$., long $124^{\circ} 16^{\prime} 48^{\prime \prime} \mathrm{W}$. The distance from epicenter to well USW H-5 was approximately $789 \mathrm{~km}$, and the first water-level response was detected at 07:44 UTC. The peak water-level rise and fall in the upper interval of the well were $11.0 \mathrm{~cm}$ and $-10.2 \mathrm{~cm}$. The fluctuations damped to $1 \mathrm{~cm}$ in about 12 minutes. The peak fluid-pressure rise and fall in the lower interval were $12.4 \mathrm{~cm}$ and $-13.7 \mathrm{~cm}$ of water. The fluctuations damped to $1 \mathrm{~cm}$ in about 18 minutes. 


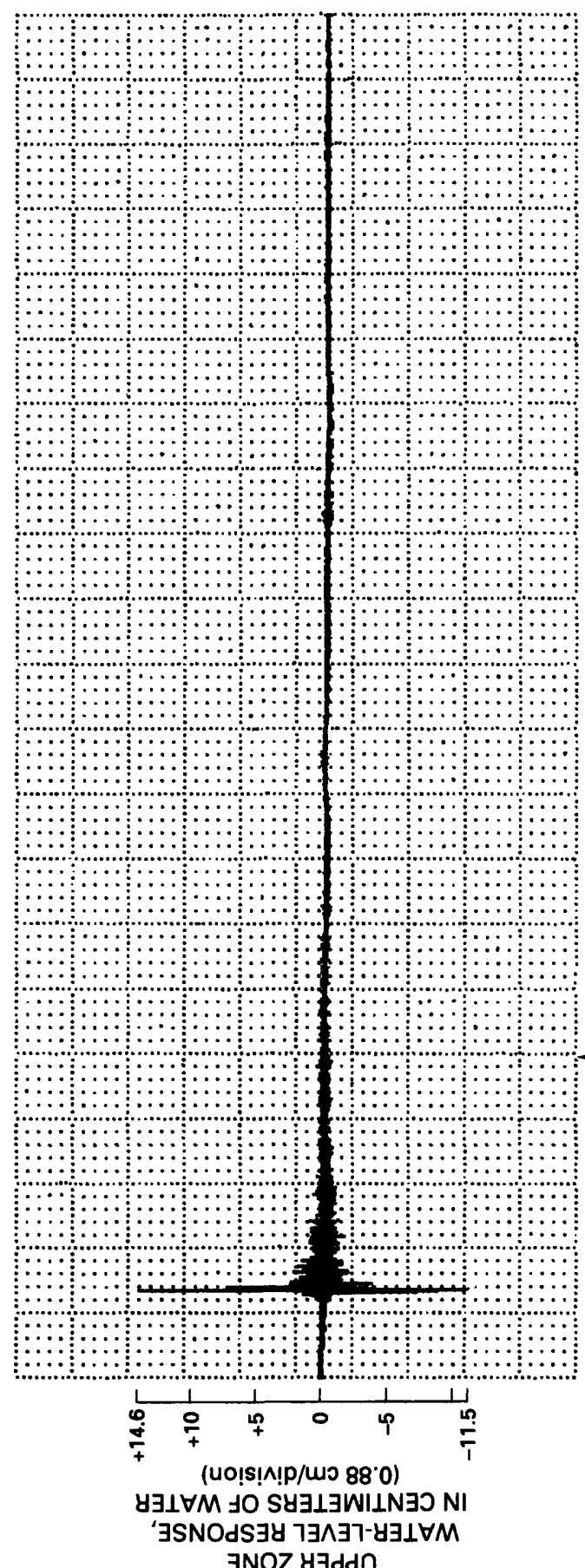

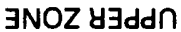

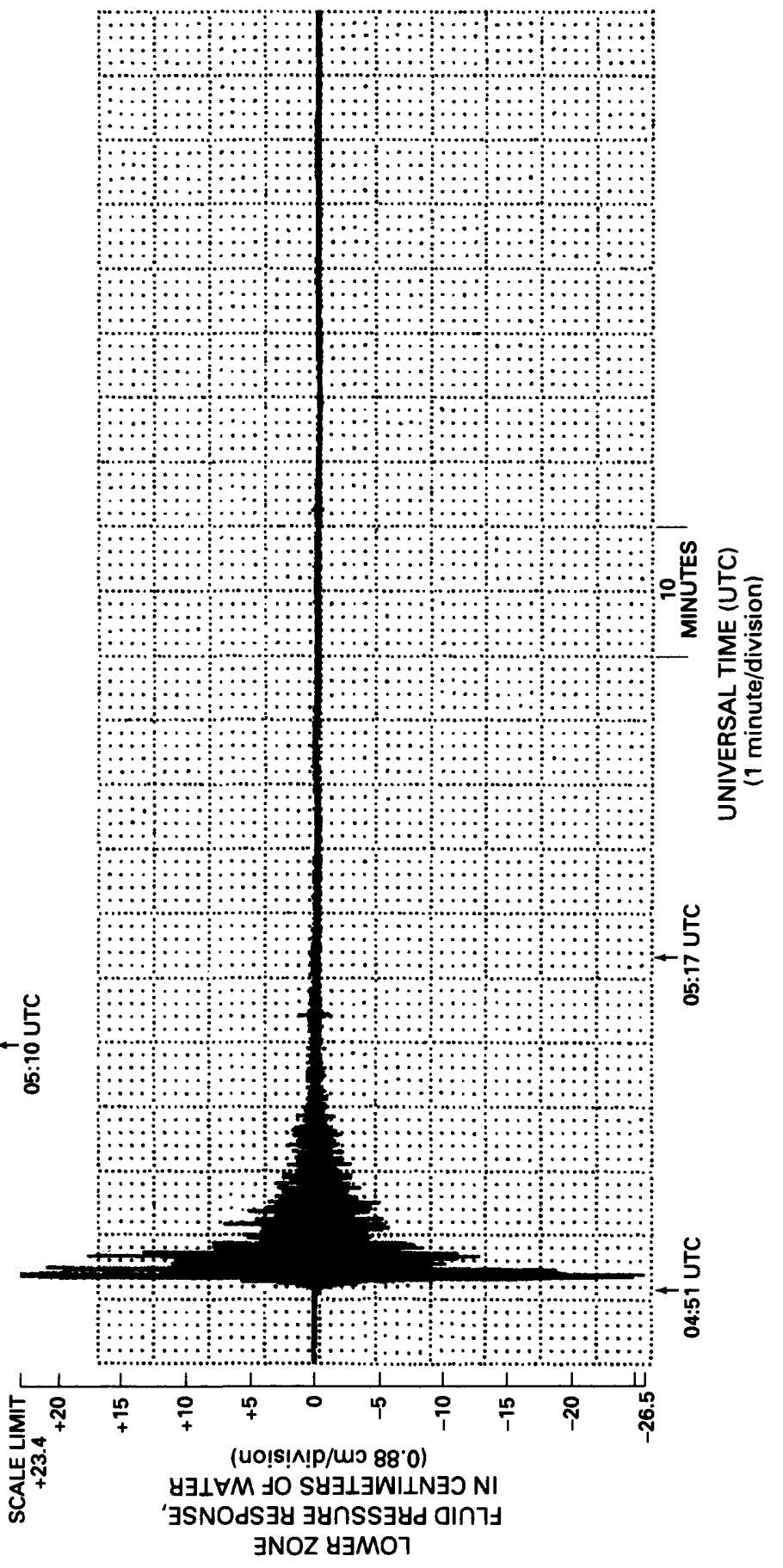

$\dot{5}$

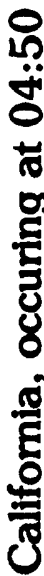

के

हูล

훙

을

온

8

8

\&

I

3

离 


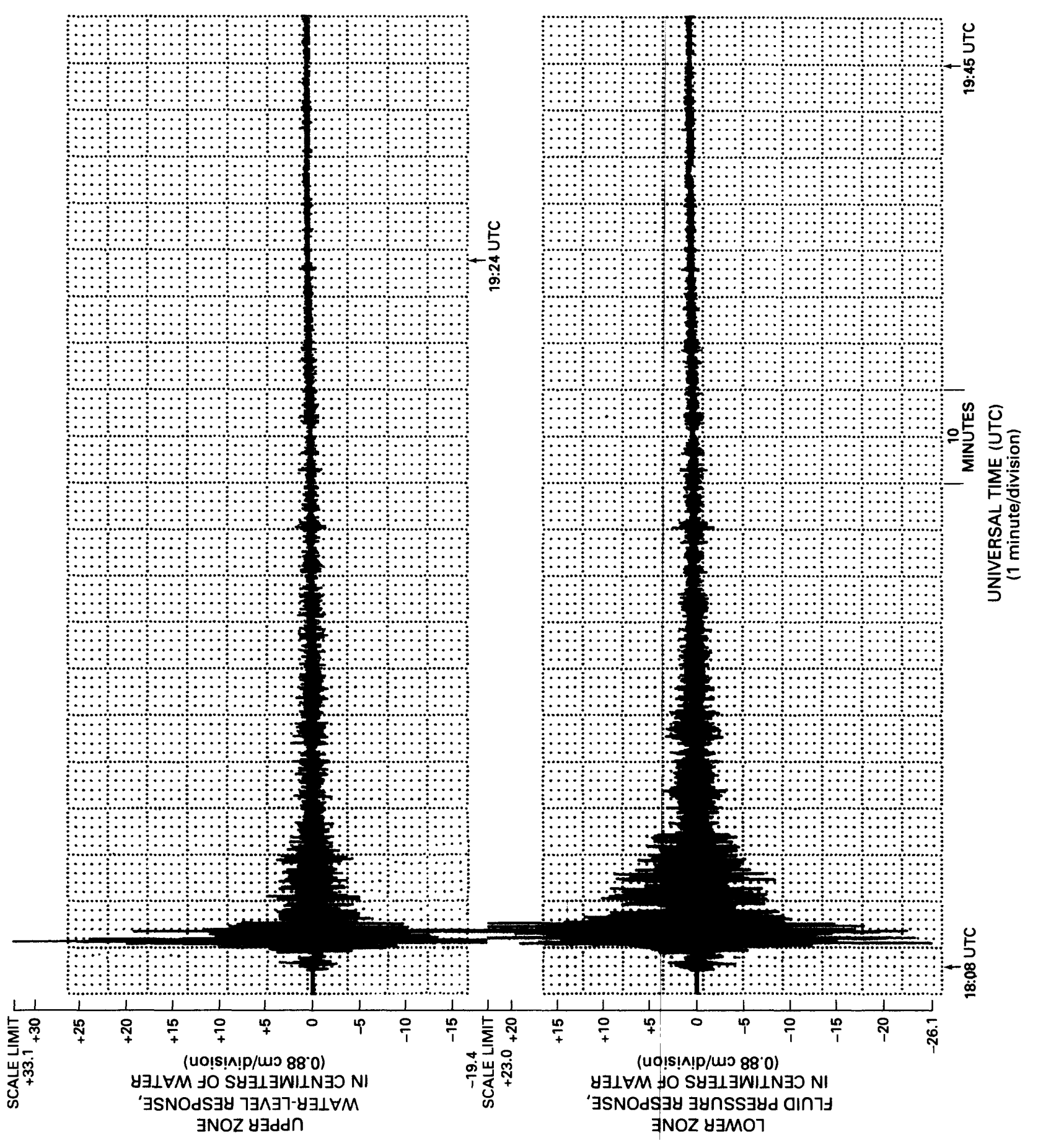



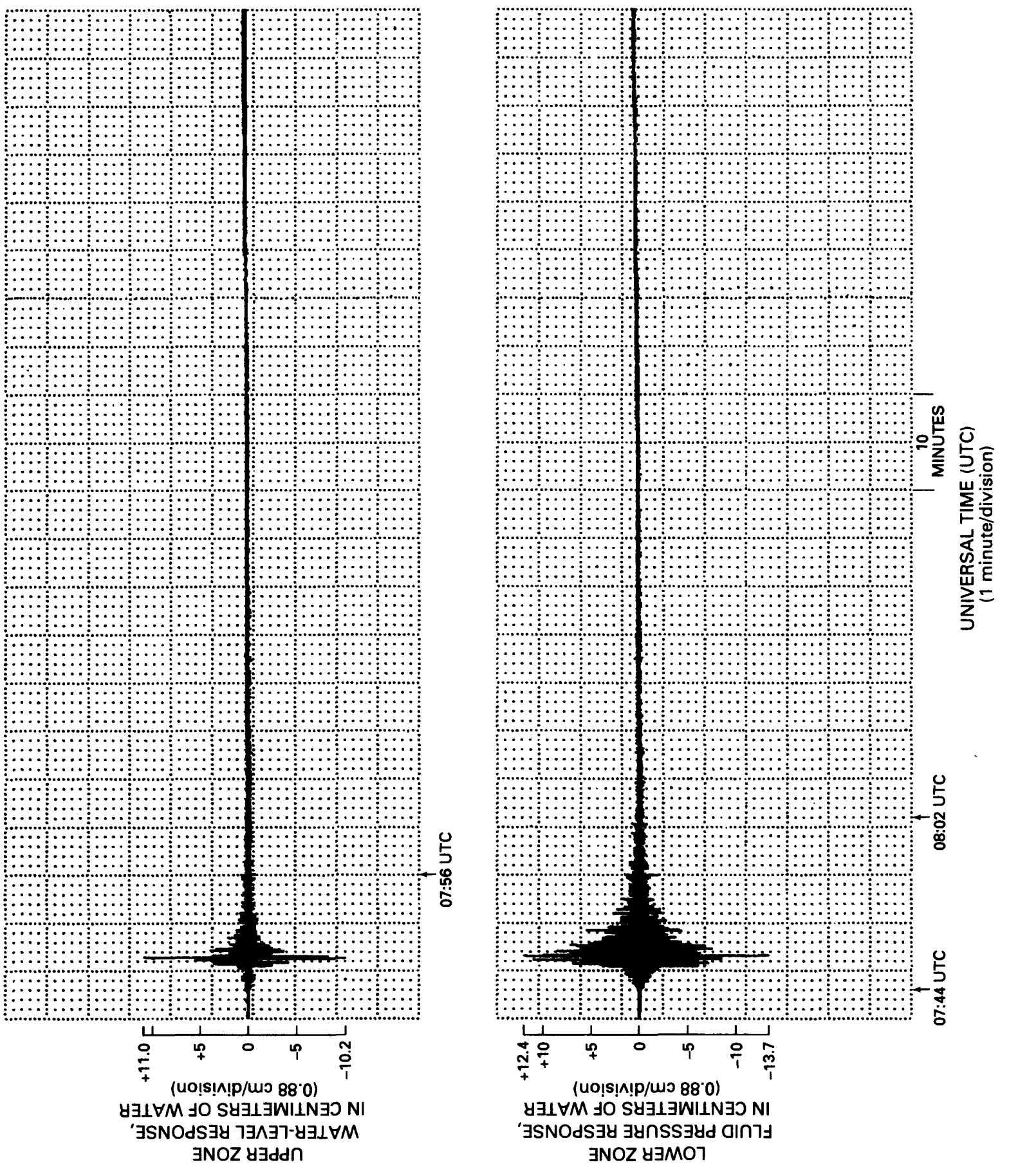

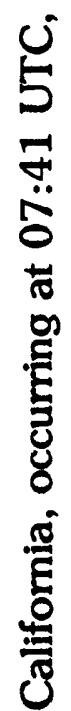

这

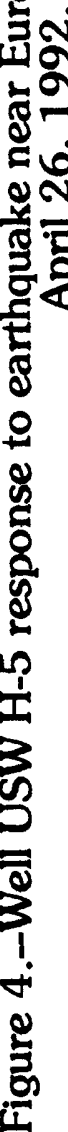



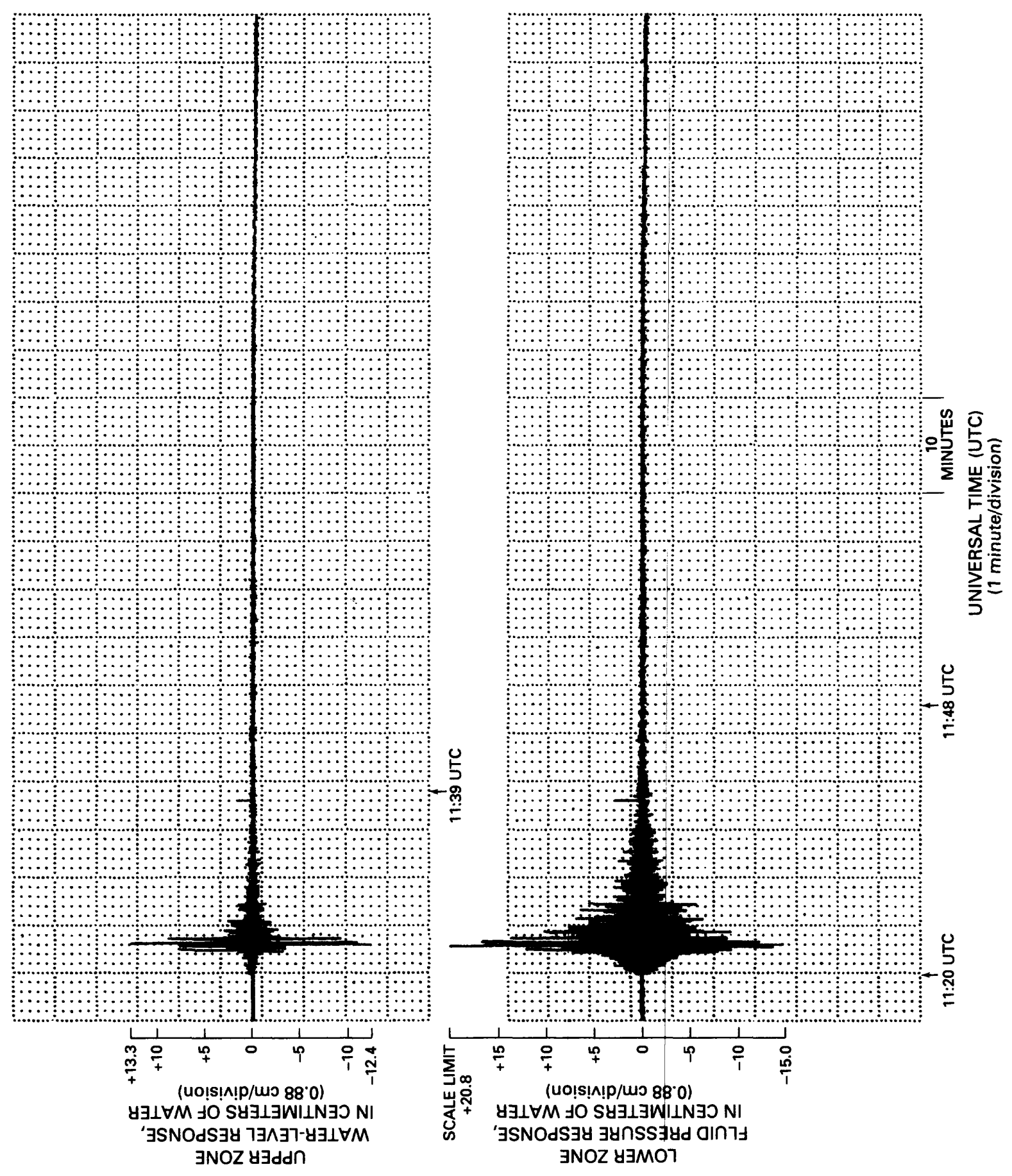

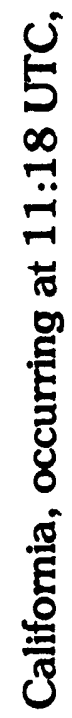

ㅎํㄴ

 
The water-level and fluid-pressure response to the northern California earthquake at 11:18:26 UTC, April 26, 1992, is shown in figure 5. The 6.6-magnitude earthquake occurred at lat $40^{\circ} 23^{\prime} 53^{\prime \prime} \mathrm{N}$., long $124^{\circ} 18^{\prime} 14^{\prime \prime} \mathrm{W}$. The distance from epicenter to well USW H-5 was approximately $789 \mathrm{~km}$, and the first water-level response was detected at 11:20 UTC. The peak water-level rise and fall in the upper interval were $13.3 \mathrm{~cm}$ and $-12.4 \mathrm{~cm}$. The fluctuations damped to $1 \mathrm{~cm}$ in about 19 minutes. The peak fluid-pressure rise in the lower interval was off scale and, thus, exceeded $20.8 \mathrm{~cm}$; the fall remained on scale and was $-15.0 \mathrm{~cm}$ of water. The fluctuations damped to $1 \mathrm{~cm}$ in about 28 minutes.

Water levels in well USW H-5 returned to pre-earthquake altitude following each of the April, 1992 earthquakes. No response to the earthquakes was detected in wells that were monitored monthly or hourly. 


\section{SELECTED REFERENCES}

Eaton, J.P., and Takasaki, K.J., 1959, Seismological interpretation of earthquakeinduced water-level fluctuations in wells: Seismological Society of America Bulletin, v. 49, no. 3, p. 227-245. (NNA.920529.0052)

Leggette, R.M., and Taylor G.H., 1935, Earthquakes instrumentally recorded in artesian wells: Seismological Society of America Bulletin, v. 25, no. 2, p. 169175. (NNA.920605.0069)

Robison, J.H., Stephens, D.M., Luckey, R.R., and Baldwin, D.A., 1988, Water levels in periodically measured wells in the Yucca Mountain area, Nevada, 1981-87: U.S. Geological Survey Open-File Report 88-468, 132 p. (NAA.890306.0113)

Todd, D.K., 1980, Groundwater hydrology, (2d ed.): New York, Wiley, 535 p. (NNA.920529.0056)

U.S. Department of Energy, 1988, Site characterization plan, Yucca Mountain site, Nevada research and development area, Nevada: U.S. Department of Energy Report DOE RW/0199, 9 v., various pagination. (HQO.881201.0002)

Vorhis, R.C., 1967, Hydrologic effects of the earthquake of March 27, 1964, outside Alaska, with sections on Hydroseismograms from the Nunn-Bush Shoe Co. well, Wisconsin, by E.E. Rexin and R.C. Vorhis, and Alaska earthquake effects on ground water in Iowa, by R.W. Cable: U.S. Geological Survey Professional Paper 544-C, 54 p. (NNA.920529.0057)

NOTE: Parenthesized numbers following each cited reference are for U.S. Department of Energy OCRWM Records Management purposes only and should not be used when ordering the publication. 